$\mathbb{T}$ periodica polytechnica

Civil Engineering

54/2 (2010) 171,180

doi: 10.3311/pp.ci.2010-2.13

web: http://www.pp.bme.hu/ci

(c) Periodica Polytechnica 2010

CASE STUDY

\section{0-year-old water towers of the Zielinski engineers' bureau}

Zsuzsanna Gábor-Szabó

Received 2009-07-08, accepted 2010-03-29

\begin{abstract}
In the first decade of the 20th century dr Szilárd Zielinski (1860-1924) and his partners designed and built the first reinforced concrete water towers in Hungary. Some of these pioneering water towers situated outside the borders of present-day Hungary - which have not yet attracted appropriate attentionhave also been considered in this study.

A formal and structural analysis shows the idiosyncracies of Zielinski's design on the basis of which his commonly accepted authorship of the tower in the town of Szolnok is questioned. In addition, contemporary documents unequivocally prove that Zielinski indeed was one of the competitors of the tender though not the winning one. The plans submitted by his bureau clearly show the typical features of his realized water towers.

Zielinski's and his associated architect partners' undeniable conceptual novelty was enabling public access into the interior of some ideally situated towers which eventuated specific structural consequences.
\end{abstract}

\section{Keywords}

water tower - Zielinski $\cdot$ reinforced concrete $\cdot$ architecturehistory $\cdot$ industrial monument

\section{Zsuzsanna Gábor-Szabó}

Department of History of Architecture and of Monuments, BME, H-1111 Budapest, Múegyetem rkp. 3, Hungary

e-mail: zsuzsi@ viztorony.hu

\section{The apostles of reinforced concrete water towers}

In 2010 the Hungarian Chamber of Engineers commemorates the 150th anniversary of the birth of its founder and first president dr Szilárd Zielinski (1860-1924), who was the first to obtain a doctor's degree at the Hungarian Royal Joseph Technical University in 1901. As a professor of the Department of Highway and Railway Engineering and an experienced civil engineer he was the introducer of the reinforced concrete building technology in the country. Albeit the theme of this paper is the study of his oeuvre in the field of the construction of reinforced concrete (RC) water towers at the beginning of the 20th century, the presentation of the inventions of his predecessors cannot be omitted.

Three Englishmen contributed to the invention of modern time concrete. John Smeaton (1724-1792) the constructor of the Eddystone lighthouse (England) obtained a quick setting hydraulic cement by the addition of pebbles and powered brick into the cement mortar in 1756. Fourty years later Rev James Parker (pre 1780 - after 1807) patented the so called Roman cement that he produced by heating and crushing the septaria nodules embedded in London Clay. Joseph Aspdin (1778-1855) continued Smeaton's research and in 1824 he patented his Portland cement that he created by burning clay and ground limestone together. The first well-known reinforced concrete boat in the world was presented at the World's Fair in Paris in 1855. By inserting a wire mesh into the mortar Joseph Louis Lambot's (1814-1887) boat illustrated the idea of combining the compressive strength of concrete with the tensile strength of iron in it. Nevertheless the man, who is commonly credited with the invention of reinforced concrete, was a French gardener, Joseph Monier (1823-1906). He constructed several garden plant tubes by coating an iron mesh with cement mortar. During the course of the following decades his invention evolved in progressively larger water tanks. In the 1860-1870s Monier erected a number of cylindrical concrete tanks supported on rustic pillars for domestic and garden water supply in Nizza, Fontenaible, Bougival, Alençon, Fontenay sous Bois et Sèvres aux Bruyères [1].

Before the end of the 19th century there were several pioneering engineers in Europe creating similar structures. The German 
Eduard Züblin (1850-1916) built his first water tower in Scafati (Italy) in 1897 and the French Edmond Coignet (1856-1915) in Toulon in 1898. The Belgian François Hennebique (18421921), who played an important role in the starting of Zielinski's career built his first approx. $500 \mathrm{~m}^{3}$ capacity concrete water tower at Dinard (Bretagne) in 1895. Hennebique set up in business as a public works contractor in Paris, but in 1892 he deviced and introduced a new system of reinforcing concrete with steel bars and stripes. His system based on sound structural design principles rapidly gained acceptance in France. From 1897 onwards he established agencies all over Europe. One of the first ones was his agency in Swansea (Wales) where his associated partner Louis Gustave Mouchel (1852-1908) built Britain's first RC water tower at Meyrick Park, Bournemouth in 1900 [1].

The exhibition in that year in Paris enabled Zielinski to get acquainted with the technique and he immediately contacted the bureau of Hennebique [4]. He acquired the rights for the application of the reinforcement system for Hungary. He made contracts with different building contractors in order to assure the dissemination of the system and most importantly to become its exclusive distributor. Each subcontractor was obliged to order the plans of any steel-structured concrete edifice from the bureau of Zielinski, who also took the task of technical supervising during the construction. The partnership formed in this way also ensured the mutual sharing of information regarding to future commissions. At the beginning the structural plans were elaborated in the Hennebique bureau in Paris, but later on Zielinski modified and adapted them to the aesthetical requirements prevailing in Hungary [4].

\section{The first commission of Zielinski's bureau}

The new system, which rendered the use of self-supporting rigid steel beams unnecessary, was still little known even for the professionals and the authorities were suspicious towards it. Nevertheless, the municipality of Budapest ordered a plan of a concrete water tower to be established for the supply of the residential and industrial area lying on a higher level of Kóbánya. This was the first occasion, when Zielinski's bureau participated in the design competition of a water tower.

Let us consider first the already existing examples outside Hungary that could have inspired Zielinski. Besides Monier's low capacity garden tanks there is estonishingly few RC water towers that had already been achieved by the turn of the century. Mouchel's Meyrick Park water tower had a $68 \mathrm{~m}^{3}$ capacity cylindrical tank with a scalloped skirt and prominent lower ring beam supported by six columns which were circumferentially braced at three intermediate levels [1]. It had no central shaft and the pipeworks ascended towards the tank without any protection. It was built for the watering of a cricket pitch.

In 1885 for the town of Landshut (Germany) G. A. Wayss (1850-1917) and M. Koenen (1849-1924) engineers designed a sophisticatedly structured $22 \mathrm{~m}$ high tower, though with a modest $59 \mathrm{~m}^{3}$ capacity which was supported on splayed concrete columns connected by curtain walling and with intermediatelevel bracing. The surviving drawings show that the tank had an access shaft up through the centre of it [1].

To the South of Paris in Bourg-la-Reine Hennebique's own villa built in 1901-1903 to demonstrate the possibilities of the exclusive use of the new material and its constructional technology was crowned by a minaret like, slim tower which held a cylindrical water tank for the watering of the garden. In its axis there was a strong shaft which was completed by four piers under the tank. On the top of the tower there was a view point.

As a licence holder of the Hennebique system Zielinski could not do but submit the plans of the Paris bureau for the competition of the Köbánya water tower. In the bequest of Zielinski researched by György Hajós the original 1:100 scaled structure plans of the Hennebique bureau can be found with the date of 7 May 1902. It presents a plain cylindrical tank with the diameter of $10 \mathrm{~m}$ supported by twelve braced columns. The access into the tank is ensured by a $1.10 \mathrm{~m}$ wide service corridor arround it, the outer wall of which is a $8 \mathrm{~cm}$ thick concrete structure stiffened by twelve T-shaped pillars.

The tower which was finally constructed in 1903 had a different outlook both in its structure and in its facade (Fig. 11. Some of the characteristic features of the forthcoming water towers can already be recognized in Zielinski's work. He applied four central and eight circumferential pillars - the latters curving out towards their base. By the horizontal bracing linking the pillars on five levels a grillage of RC beams was formed to support the $350 \mathrm{~m}^{3}$ capacity flat-bottom RC tank. Its circular wall and bottom had the identical thickness of $14 \mathrm{~cm}$ and the diameter increased to $10.22 \mathrm{~m}$. The tank's wall was strengthened by a $25 \mathrm{~cm}$ thick ring beam and it could hold the water level on $4.60 \mathrm{~m}$ height [4].

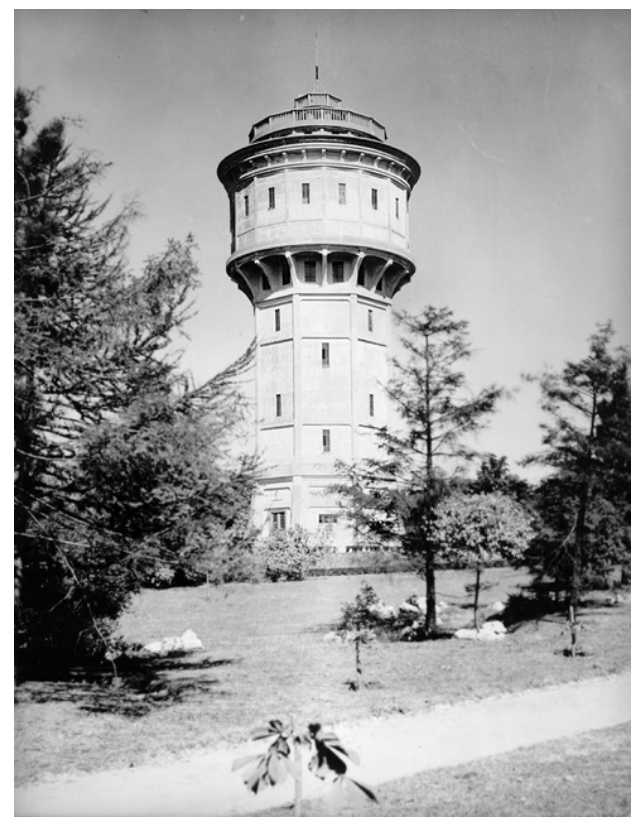

Fig. 1. The first RC water tower in Hungary built in Kóbánya in 1903. The $\mathrm{RC}$ fence encircling the park where it was erected was also one of Zielinski's patents. Courtesy of Fôvárosi Vízmúvek Zrt. 
The shaft of the $33.30 \mathrm{~m}$ high tower is formed by connecting the pillars of curtain walling which is evenly pierced by small sized windows. Inside, along the shaft's wall straight stairways enable the access through seven platforms towards the underside of the tank. The roof and the turret on the top of it can be reached through a ladder in the core of the shaft which is continued up through the centre of the tank.

The horizontal beams supporting the tank corbel out of the circumferential pillars according to the width of the service corridor surrounding the tank which is $65 \mathrm{~cm}$ wide. This jutting out of the head of the tower gives it a mace-like character which was peculiar to the contemporary water towers holding an Intze Type cast iron tank. The design of the corridor's outer concrete wall articulated by slim concrete wall bandings resembles the concept of the timber structured covering of the railway water towers belonging to the aforementioned type.

The foundation of the tower is a $20 \mathrm{~cm}$ thick concrete plate which is strengthened with a grillage of beams. A characteristic technical feature of the ironwork of the construction is that for holding the iron rods at their designed position flat irons were used. They were pierced and the longitudinal irons were pulled over its holes.

The tower was constucted by the Grünwald and Schiffer Building Enterprise who finished it at the end of 1903.

\section{Common features of Zielinski's water towers 1904- 1912}

Parallel to the construction of the first RC tower ever built in Hungary Zielinski's bureau already had a commission for a three times larger elevated water reservoir to be built for the municipal water supply of the town of Szeged (Fig. 2). Compared to the tower of Köbánya it can be concluded that a sort of structural enlargement happened which was certainly required by the $1004.8 \mathrm{~m}^{3}$ capacity tank to be held on a ten metres higher level. With his collaborators: Zsigmond Jemnitz as the structural engineer and Flóris Korb (1860-1930) as the architect he kept certain design traits already elaborated in his first project. The basic concept remained the same only some structural innovations appeared which contributed to the maturation of his own water tower style. A new element is the ring of the eight free-standing pillars around the octagonal shaped solid shaft. In order to obtain this elegant, shadow and light articulated tracery effect he had to apply relatively slender circumferential pillars. The phenomenon of the buckling of slender concrete pillars under excessive compression was already known by the time. The cross-bracings taking the form of concrete beams linking the pillars and, if present, the central shaft had a few configurations at that time. The solution that Zielinski chose is an early and unique example of using intermediate floor levels to stiffen the vertical structures.

Hennebique himself who was charged with the construction of the municipal water supply tower in Newton-le-Willows (England) in 1904 chose to follow a very different structural

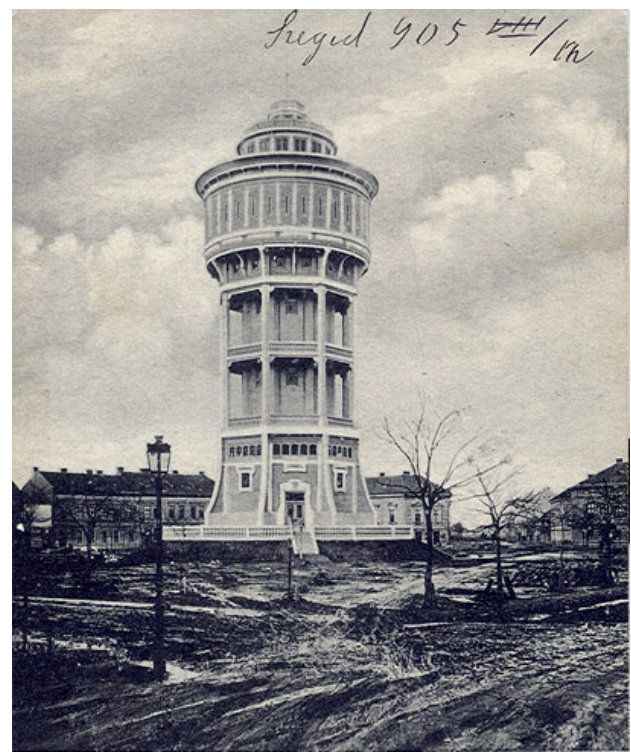

Fig. 2. The RC water tower of Szeged celebrated the $102^{\text {nd }}$ anniversary of its construction after its full scale renovation in 2006. Source: private postcard collection of András Lánczi.

trend (Fig. 3). His $1364 \mathrm{~m}^{3}$ capacity tank elevated to $35 \mathrm{~m}$ high was a rather flat and expanding cylinder with a 1:5 ratio as for its inner height to its diameter, compared to Zielinski's 1:2 ratio. It had a very slender central shaft hidden behind the concentric arrangement of pillars: 12 in the inner and 16 in the outer ring. The pillars were cross-braced at three levels which were of equal heights. On the tank roof it had a small cupola with a doorway and windows where the core of the shaft leading through the tank had its ending. The tank had to be ventilated and this was the reason of the emergence of this element besides the enabling of the roof access. The constructional concept of this tower (being the world's largest RC tower in 1905) was the emphasizing of the grillage of supporting beams bearing a huge load which was obviously a good demonstration of the Hennebique reinforcement system whose essence was the combined ironing of the pillar-beam-slab structural unit of the loadbearing structure $[4]$.

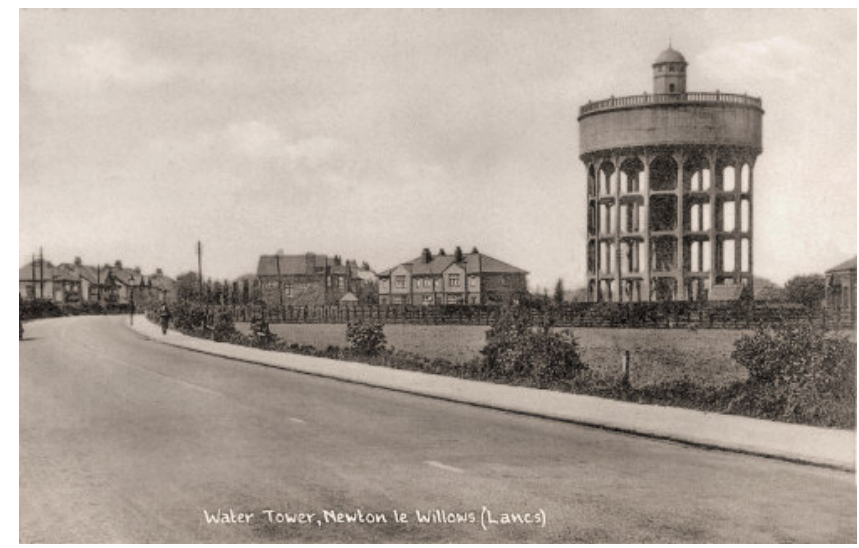

Fig. 3. The RC water tower in Newton-le-Willows (England) designed by F. Hennebique, came into service in 1906. Source: http://bp2.blogger.com/_RmEb7YAadxI/SIewnUNIyWI/AAAAAAAAAQI/jfl _0OU7MD0/s1600-h/nlw.jpg (accessed at 20/06/2009) 
The tank had a slight corbelling and on its upper rim there was a baluster railing made of RC. The tank's outer wall had no other decoration or openings, it resembled a huge round shaped container raised on a truss of pillars.

Considering Zielinski's and Hennebique's first RC water towers built with a difference of one year after each other, by a momentary comparison it can be concluded that while Newton-leWillows was designed for the functional minimum of a waterretaining structure, the tower in Szeged (and in Kóbánya beforehand) attempted to use concrete architecturally. Zielinski's first two towers already have the architectonic trichotomy of the base, trunk and head, which made these edifices resemble urban buildings. The filling of the space within the outer ring of pillars in the case of Kóbánya-tower, and giving it an articulated groundfloor facade separated from the upper part of the shaft with an accentuated cornice shows a design trend opposite to the constuctional attitude of Hennebique coming presumably from the contemporary steel-structure building.

With his design of the Szeged tower in 1904 Zielinski and his architect partners Flóris Korb and Kálmán Giergl (1863-1954) created the prototype of RC water towers holding a RC tank on free-standing, braced pillars together with a polygonal, infilled central shaft and an accentuated groundfloor level, which is infilled up to the first cross-braces of the circumferential ring of pillars. The scaffolding and the concrete works of the tower were realized by the Henrik Freund and Sons Co. supervised by Kálmán Illés.

The aforementioned features were common in all the five of his water towers that he presented not only in picture albums and drawings but in models as well on the architectural exposition of Leipzig (Internationale Baufachausstellung) in 1913. These were the water towers of Kőbánya (1903), Szeged (1904), Belcsény (ca. 1905), Temesvár (ca. 1906) and Margaret Island, Budapest (1911) [4]. In fact, according to the surviving documents of his bequest we are informed of at least 14 addititonal water towers that he had been dealing with before 1913. The most recent one on Istenhegy (Budapest, Eötvös út) had been finished at the time of the exposition. Since he had to choose the most significant ones of his realized works besides his other RC constructions, he selected the towers with the largest capacities in order to demonstrate the successful application of RC structures designed by his bureau. His presented works were highly appreciated indeed and he was awarded with the gold medal of the town of Leipzig. The author tried to find documentary evidence for all the remaining 14 towers in question, but with a rather disappointing result. Most probably, it was the water tank in Alag, which came into being from these tanks of smaller capacity. About the realization of the others there is still no certain information.

Among the water towers which Zielinski himself regarded as his most significant ones, there are two which have not yet received appropriate attention, presumably due to their location outside the present borders of Hungary. However, their study clearly demonstrates the development of Zielinski's design concept, which eventually lead to the creation of his most famous tower, the one on Margaret Island.

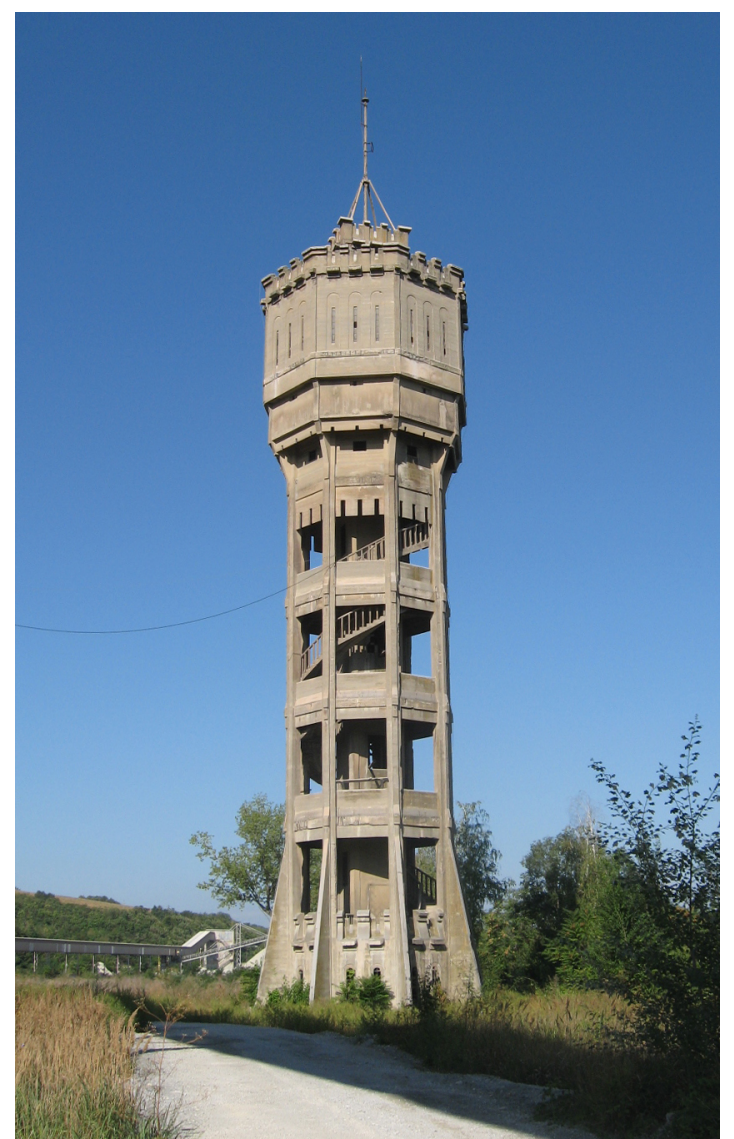

Fig. 4. The actual state of the water tower on the territory of the Lafarge Cement Factory in Beočin. Photo: Miroslav Solaja, Lafarge Cement Factory Beočin.

The evolution began with the tower at Beočin (Belcsény), (Fig. 4) situated in present-day Serbia, where production of Portland-cement began for the first time in Hungary in 1870 [4]. In the bequest of Zielinski, the tower's dimensioning calculations can be found (Fig. 5). In addition, there is an undated plan of very poor preservation attached to op. no 165 , showing the foundation of the tower and the section of the service space below the tank. The inscription on the plan states that the capacity of the tank is $350 \mathrm{~m}^{3}$, and so does the caption below the photo of the tower, preserved in the Hungarian Museum of Environmental Protection and Water Administration as well. This fact must be emphasized since Gy. Hajós [4] gives the capacity of $300 \mathrm{~m}^{3}$. The water tower shown in the photo has eight slender pillars curving out towards their base. Its central solid shaft is framed by four pillars. The ground-floor level is infilled having two arched oblong windows on each side. The pillars are braced on five levels, at equal distances from each other. The access to the tank is through winding staircases, which are in the open space between the outer pillars and the central square-shaped core of the shaft. The tank is on a slight cantilever, which is formed by the staggered outer wall of the service space under it. The access to the roof is via a cylindrical shaft through the 
tank. Around the tank there is a corridor, ca. $70 \mathrm{~cm}$ wide, the outer wall of which is decorated with three slender openings contoured by curved plastering on each side. The doorway to the roof of the tank opens from a prismatic turret with dentile cornice. All the other mouldings have a similar design. The tower has been standing on the territory of the Lafarge cement factory since 1905 .

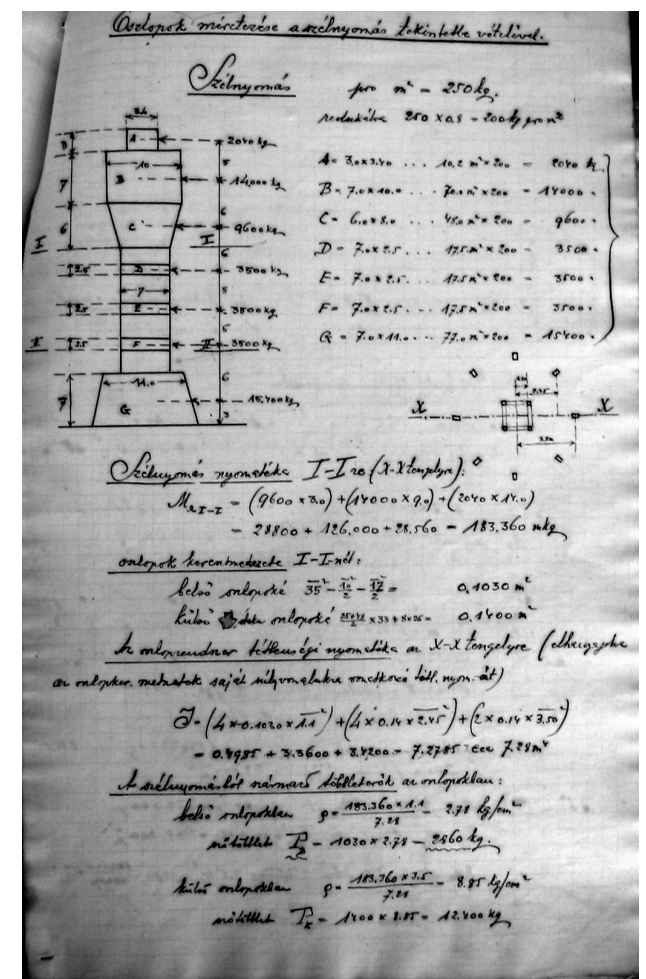

Fig. 5. The dimensioning calculations of the pillars with regards to windpressure attached to the plans of the Beočin water tower. Source: Archives of the Hungarian Museum of Transport.

It was approximately at the same time, when the tower of the Józsefváros railway station at Timişoara (Temesvár), in presentday Rumania was built (Fig. 6). The Hungarian State Railways (MÁV) invited the bureau of Zielinski to submit the plans for a RC tower of $500 \mathrm{~m}^{3}$ capacity for the tender. In the bequest there are three plans. Two of them are only partially elaborated, but all of them have a tank divided into two compartments having $250 \mathrm{~m}^{3}$ capacity each, and an octagonal shaped high-pitched roof with eight skylights and a finial on it. Also common to all is the closed groundfloor level topped with a baluster-railing made of RC. The arrangement of the supporting pillars is identical in two of the versions: the central solid-sided shaft has four pillars at its corners and it contains a staircase; and in the outer ring there are eight free-standing slender pillars each with an outcurving end at groundlevel. The third version does not have a central shaft, it is apparently supported by the eight circumferential pillars that are decoratively braced at the midpoint of their height, as shown in Fig. 7. The version in Fig. 8 does have a central shaft and its free-standing pillars are braced at the same level. A special feature of it is the lack of the service floor level underneath the tank. Fig. 9, on the other hand shows an un-

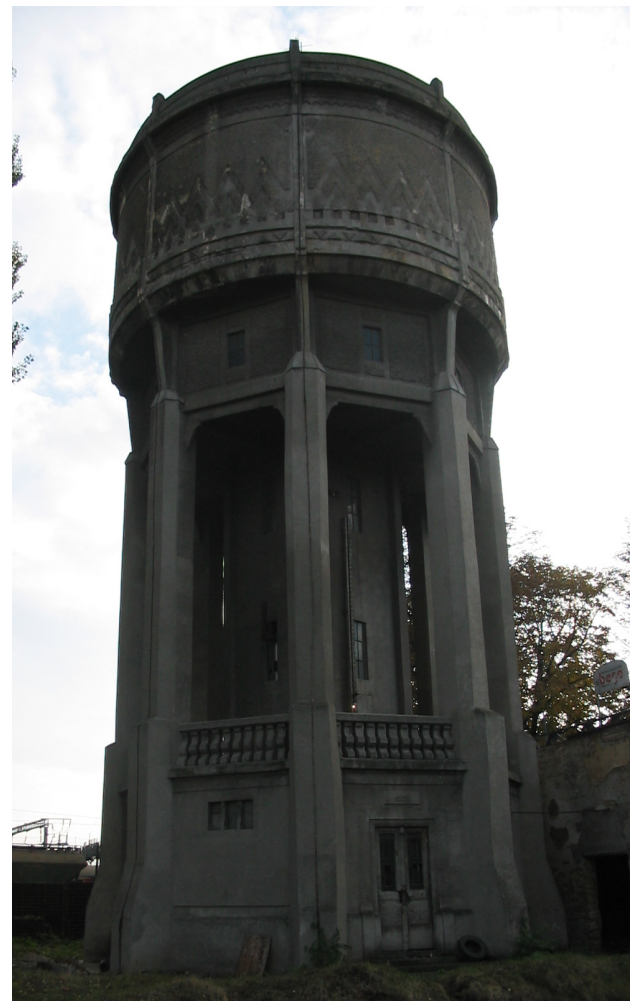

Fig. 6. In Timişoara Zielinski constructed a railway water tower. Photo: author

braced version, closely resembling the realized tower. It holds true regarding not only the structure but the decoration as well. In this third plan, the height of the tower is $28.6 \mathrm{~m}$, the lenght of

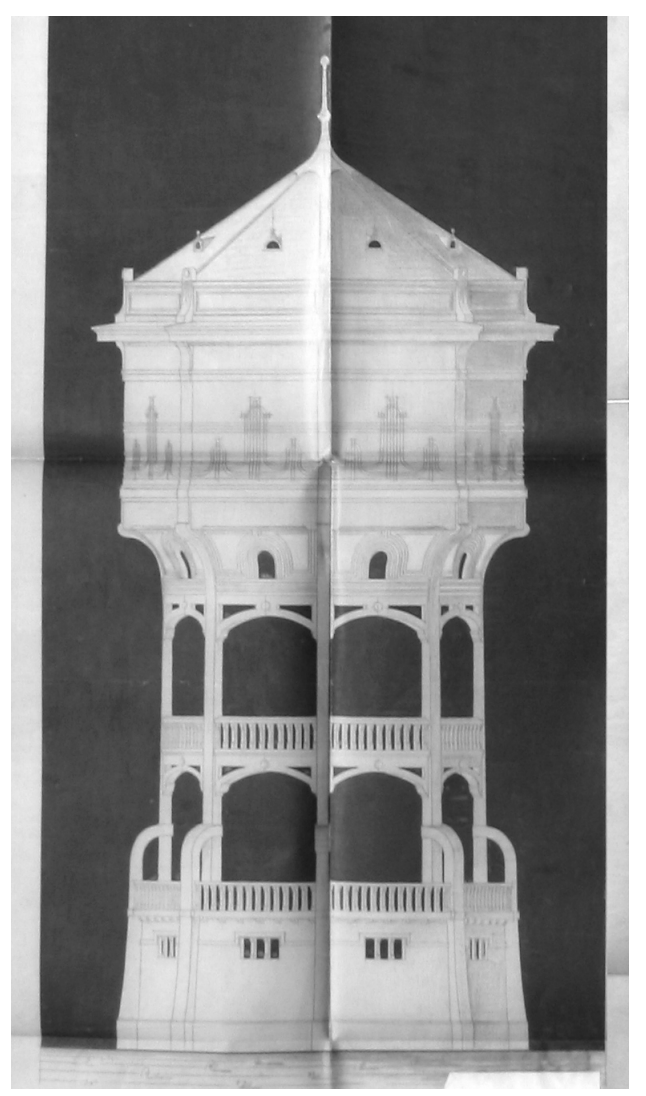

Fig. 7. The shaftless version of the Timişoara water tower with braced pillars. Source: Archives of the Hungarian Museum of Transport. 
the unbraced pillars is $9 \mathrm{~m}$. The pillars seem to be much more robust in the photograph than in the plan. This tower was built by H. Freund and Sons, the contractors, who constructed the tower in Szeged.

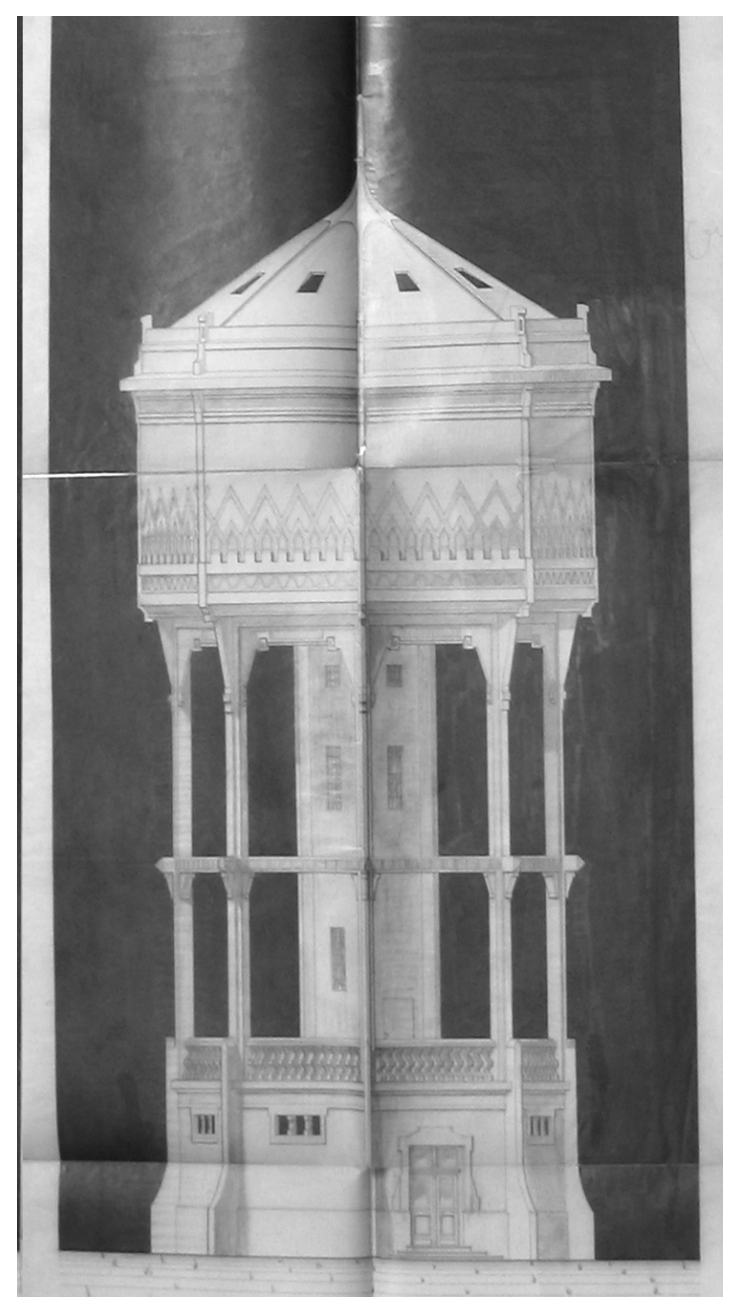

Fig. 8. A version of the Timişoara water tower which does not have a service floor level underneath its tank. Source: Archives of the Hungarian Museum of Transport.

The novelties represented by the tower of Temesvár compared with the earlier ones are the high-pitched roof structure, the unbraced reinforced concrete pillars and the enhancement of the service space below the oversailing tank. These three features are fully developed in the artful design of the tower on Margaret Island (Fig. 10.

This tower in the capital city of Hungary has a structural experiment in addition. The $600 \mathrm{~m}^{3}$ capacity tank inside has an Intze Type I shaped bottom. It means that the central portion of the bottom of the cylindrical tank consists of an inverted shallow dome and its outer part is an inverted truncated cone. The cone and the dome converges on a $\mathrm{RC}$ ringbeam connecting the eigth circumferential pillars. This solution required a complex shuttering to form the tank's floor and was a great tour de force, since Intze Type tanks had always been made of steel before. The architect collaborating with Zielinski, Rezső Vilmos Ray (1876-1939), enriched the three features previously introduced in the tower at Temesvár: the high-pitched roof was topped with

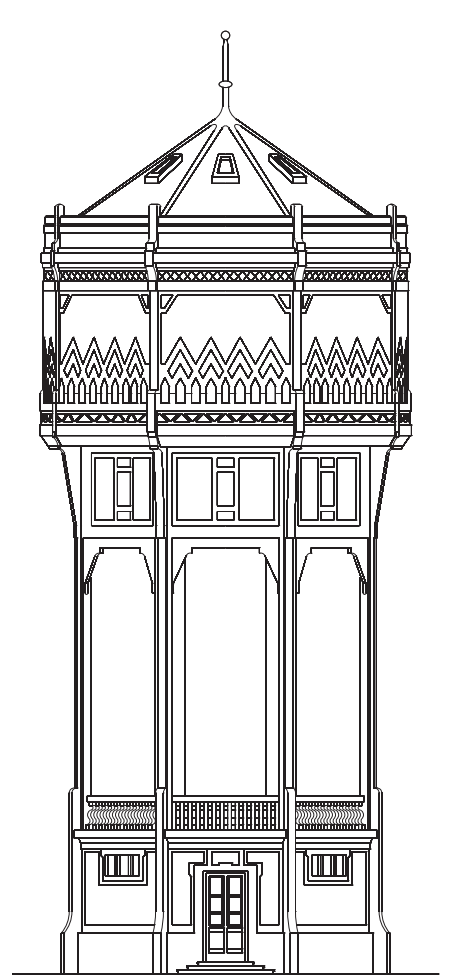

Fig. 9. The elaborated version of the Timişoara water tower to be constructed in 1906. After: Archives of the Hungarian Museum of Transport.

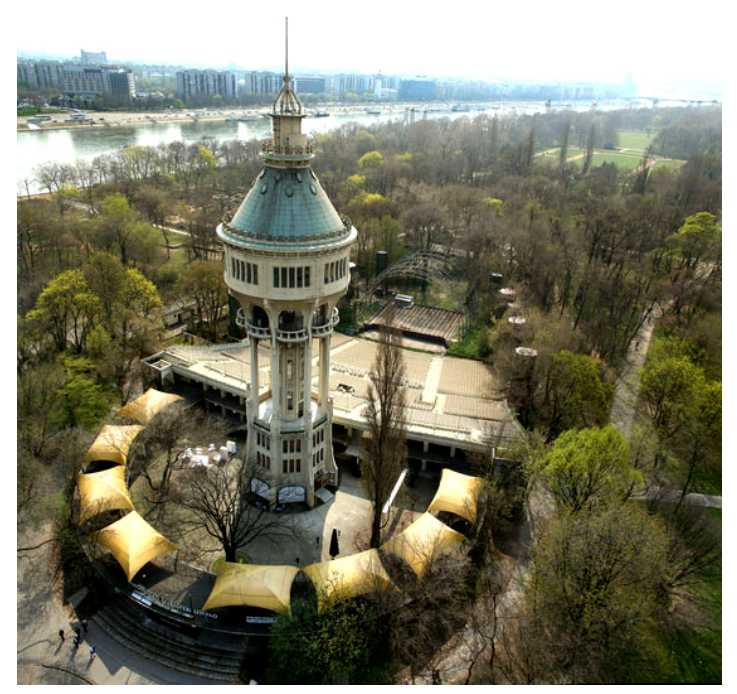

Fig. 10. 98-year-old water tower on Margaret Island. Photo: Balloide Kft.

a panorama terrace and with an observatory turret; the slab beneath the tank appears as a chain of loggias between the pillars, accessible through large glazed doorways; the $13.5 \mathrm{~m}$ long unbraced pillars and the three-storey high, closed ground level are related to each other reproducing the golden ratio. This tower has been built by the contractors Kemény \& Co.

The successful series of Zielinski's watertowers ends with the Istenhegyi tower (Budapest, at present, XII. Eötvös út) constructed in 1913 by the Fodor and Reisinger Co. (Fig. 11). This tower has an Intze Type I shaped RC tank of $200 \mathrm{~m}^{3}$ capacity and shows several features discussed above. It presents a mixture of the elements used in his previous buildings, but in a simplified 
manner. The remarkable splaying of the free-standing unbraced circumferential pillars is introduced here as a structural novelty in order to make the head of the tower look lighter. Due to the advantageous power play of the Intze Type tank, which reduces the horizontal forces on the supporting ring beam of the tank to a minimum, the tank significantly over-sails the shaft without the use of massive cantilevers.

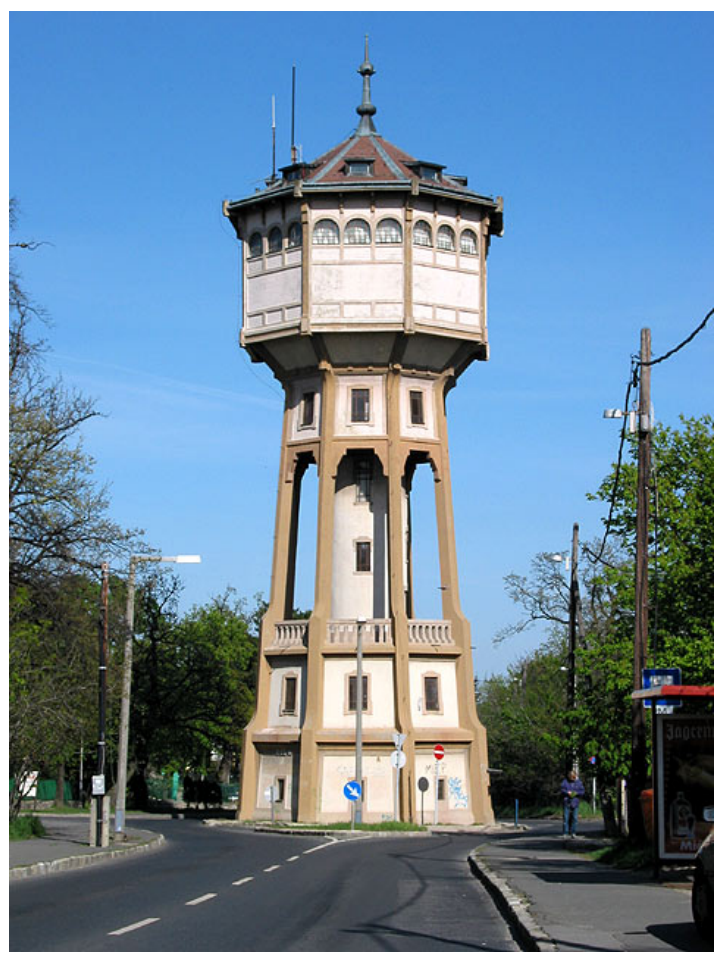

Fig. 11. At the junction of Eötvös and Fülemüle út was raised Zielinski's latest water tower. Photo: András Lánczi

Taken the whole oeuvre of RC constructions of Zielinski's bureau together, it can be observed that he had a very good sense for this new material and building technique and had the ability and the strong intention to cooperate with architects to give the load bearing constructions in such an appealing form that makes $\mathrm{RC}$ popular with the investors. On the occassion of a lecture delivered by him in 1906 with the title „Iron-framed concrete and architecture”, he declared it to be ,essential that the engineer subordinates his structures to the architect's intentions in order to achieve an aesthetical effect. This is the only way to find the appropriate form of the material and the construction." [4] His experience came from the fact that he as the chief designer was the only person who took the responsibility for the feasibility and durability of his realized water towers. By 1910 when the first Hungarian RC design regulation was published by the Reinforced Concrete Committee (Magyar Mérnök- és ÉpítészEgylet Heti Értesítője. 1910, January 2. pp. 1-6), Zielinski already had all the four of his most important water towers constructed certainly among the numerous other RC structures that he was commissioned to establish. His profound theoretical and practical knowledge gave him the audacity to create bold and appealing RC structures never conceived before.

\section{Idiosyncracies of Zielinski observed in his plan sub- mitted for the tender of the tower of Szolnok}

Three major reference works [4-6] containing basic information regarding the oeuvre of Zielinski consider the water tower in Szolnok as one of his realized buildings. The comparison of the plans in the bequest under op. no 958 and the actual tower situated on the present-day Eötvös tér raised the author's suspicion that there is some mistake with this attribution. Before going into details let us examine the idiosyncracies of Zielinski by the study of his plans.

The covering letter of 22 November 1908 signed by Zielinski attached to the tender plans of the Szolnok water tower mentions two versions (Figs. 12, 13) in the contents list. The front elevations of both versions are preserved and for one of them the 1:100 scaled longitudinal and cross-sections plans can also be found in the bequest (plan b in Fig. 14), as for the other one, only a free hand sketch of the longitudinal section remained (plan a). The common feature of the versions is the design of the $600 \mathrm{~m}^{3}$ capacity tank: a one-compartment flat-bottom RC tank with the access shaft hemmed in by the inner cylindrical wall of the tank, where a steep ladder leads towards the roof. The basic loadbearing structures of both plans are the four inner pillars framing the infilled central shaft, and the eight outer pillars curving out towards their base as usual. The design of the closed groundfloor level with the height of $7.20 \mathrm{~m}$ is the same and both versions have a baluster railing on the top of it. This motive finds its counterpart on the tower at Temesvár which can be regarded its immediate predecessor. The shaft contains the staircase which leads up to the service area below the tank. Between the two versions two major differences can be observed which, nevertheless, does not effect the structural arrangement of the basic plan. Version 'a' has a simple high-pitched octagonal roof with skylights just as the Temesvár tower. Its circumferential pillars are braced at two levels linking the pillars to each other and with radial beams to the shaft as well. Plan 'b' is a further developed version of plan 'a'. Presumably the planned position of the tower in the city of Szolnok on the market place gave the idea of enabling public access to the floor beneath the tank. Just like in Temesvár, version 'a' restricts this space to the technicians only and thus infills the space between the pillars at the height of the cantilevers on which the over-sailing of the tank has its supports. In contrast with this, version ' $b$ ' still has the braces at two different levels but the floor slab under the tank remains open. It has a $\mathrm{RC}$ baluster railing just like on the top of the groundfloor level. This points to the fact that the tower was intended to become a viewpoint as well accessible by the citizens. In order to ensure the safety of the drinking water from pollutants, this was the highest level where the public could reach. The solution resembles that of the tower on Margaret Island, where curved loggias emerge between the pillars at the same position. The RC water tower of Siófok (designed by Árpád Gút and Jenő Gergely in 1912) applies a very similar arrangement too. Version 'b' has 
another new element in virtue of which it can be considered as the missing link between the realized towers in Temesvár and Margaret Island. This is the structure of the roof. Version ' $b$ ' still has a high-pitched octagonal roof but it is crowned by a small octagonal turret with a finial on its top. This architectural element has already emerged in the previous towers except for Temesvár. Hence we witness a design experiment here the result of which is the elegant cone shaped roof of the tower on Margaret Island topped with a cylindrical turret surrounded by the accustomed RC baluster railing.

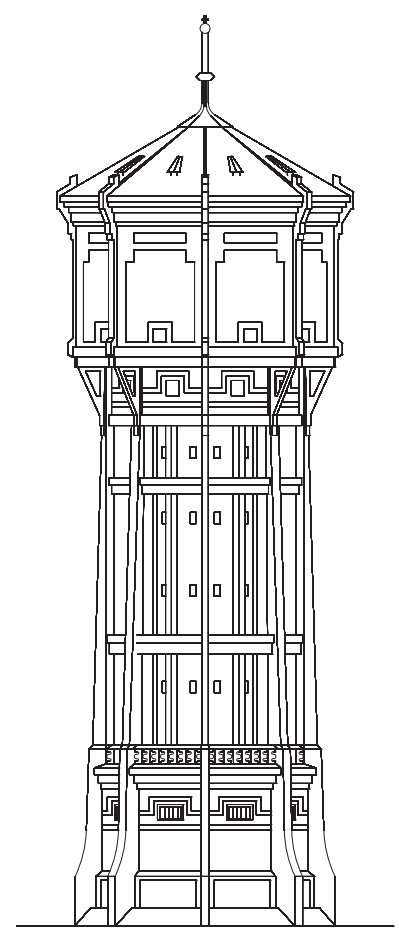

Fig. 12. Front elevation of the version 'a' of the tender plan for the Szolnok water tower. After: Archives of the Hungarian Museum of Transport.

The tower realized in Szolnok in 1910 does not have anything in common with either of Zielinski's versions. The story of the tender process may answer the question, why neither of them has been accepted by the municipality of Szolnok.

\section{The project of the Szolnok tower}

Following the serious cholera and typhus epidemics convulsing the town during the 1890 s, the leaders of the municipality took the general water supply scheme of the town into consideration. Since artesian wells could not satisfactorily supply the citizens, the plan of the establishment of the local water works arose. In 1902 József Varga, the designer of the water works in Budafok, offered his services to the municipality in elaborating a preliminary study considering the foundation of a scheme based on the retrieval of water from the river Tisza. By 1903 the plans of the whole network was ready to be constructed. The municipality took a loan of 2 million crowns from the Hungarian National Central Savings Bank and finally at the end of 1908 the public procurement procedure could begin.

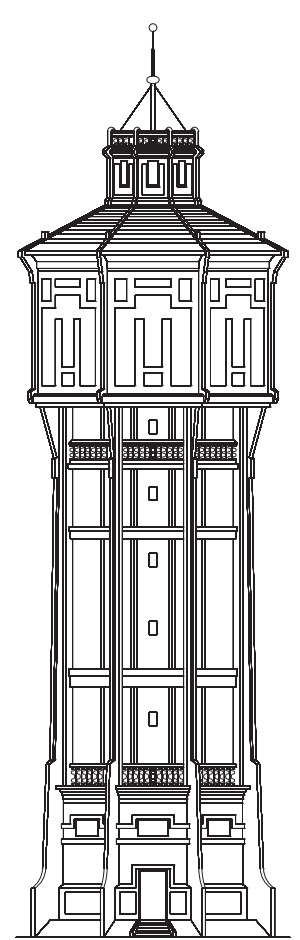

Fig. 13. Front elevation of the version ' $b$ ' of the tender plan for the Szolnok water tower. After: Archives of the Hungarian Museum of Transport.

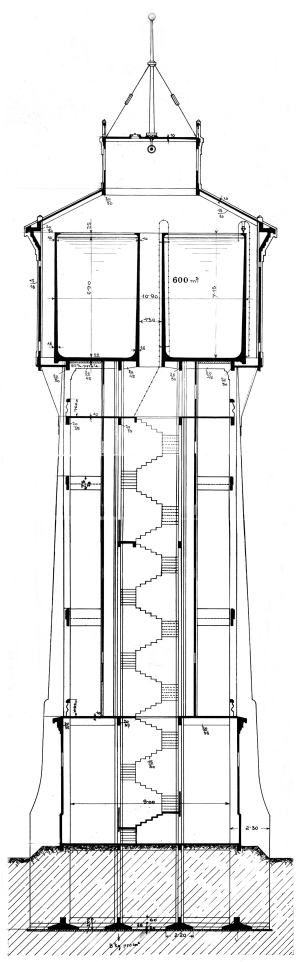

Fig. 14. Longitudinal section of the version ' $b$ ' of the tender plan for the Szolnok water tower. Source: Archives of the Hungarian Museum of Transport.

The calling for tenders divided the operations into eight groups of works among which the building of the water tower was one. The cost estimate of it was 70,000 crowns. The deadline for the submission of tenders was 25th November 1908 leaving one month for the execution of the plans. Thirteen tenders arrived on time for the building of the water tower. Three of 
them was a brick construction, the rest was made of RC. Among the competitors was the Pittl and Brauswetter Ltd. (later Beton, híd és mélyépítő Rt.) a contracted partner of the Zielinski bureau. Including the cost of the plans $(8,000$ crowns according to the aforementioned cover letter of Zielinski) they calculated the total price of the construction to be 109,213 crowns. Prior to the decision of the town councillors, the tender plans of the water towers were exhibited in the registry office of Szolnok and the procedure of the selection got a great publicity through the local newspapers. The outlook of such a landmark, taller than all the existing buildings of that time in the town, was not indifferent for most of the intellectuals in Szolnok and their opinion and fears occasionally appeared even in print. The newspapers reported that the first proposed winner was the contractor offering the lowest price without the consideration of the incomplete and inaccurate tender plans that he submitted. On the general assembly of 11 January 1909 a heated debate evolved over the selection of the contractor which ended in voting. The town councillors rejected the inadequate plans proposed and declared Ede Ast \& Co. the winner of the contract, who estimated a cost of $80,508.10$ crowns. This price was approx. 25\% less than the one offered by Zielinski's partner. It should be noted, that this was not the first time, when cost efficiency determined the choice of the tower's designer. The same factor was in favour of Zielinski six years before in Szeged.

The construction of the water tower in Szolnok took nine months. By February 1910 the whole water supply network was in operation. The water tower of Ede Ast still exists, although in a poor state. (Fig. 15, This fact is all the more regrettable, because it contains a uniquely structured tank with eight pillars standing in it. Further details of this tower were presented in the MSc degree project of the author [3].

\section{The appreciation of the 100-year-old water towers}

Generally speaking the attitude of the national heritage authorities did not favour the early RC constructions either in Hungary or abroad in the second half of the 20th century. Numerous works of engineers fall victim of the world wars and several were demolished afterwards. As for the water tower of Newtonle-Willows M. H. Gould and D. J. Cleland published that its tank cracked circumferentially when first filled [2]. It was repaired three times during sixty years but its problems persisted. Finally it was declaired redundant in 1966 and demolished in 1979 [1].

The first RC water tower in Hungary had the same fate: Zielinski's first water tower in Kőbánya was blown up owing to city planning reasons on 23 December 1968. (Fig. 16.) His second water tower in Szeged is the best preserved and maintained among all the towers mentioned in this paper. It is a listed industrial monument still in use since 1904. During 2005-2006 it was entirely renovated including the circumferential strengthening and reinsulating of its tank. (Fig. 17) According to Zielinski's original intentions the tower's reuse concept welcomed the citizens' aim to make the inside of the tower and its loggias ac-

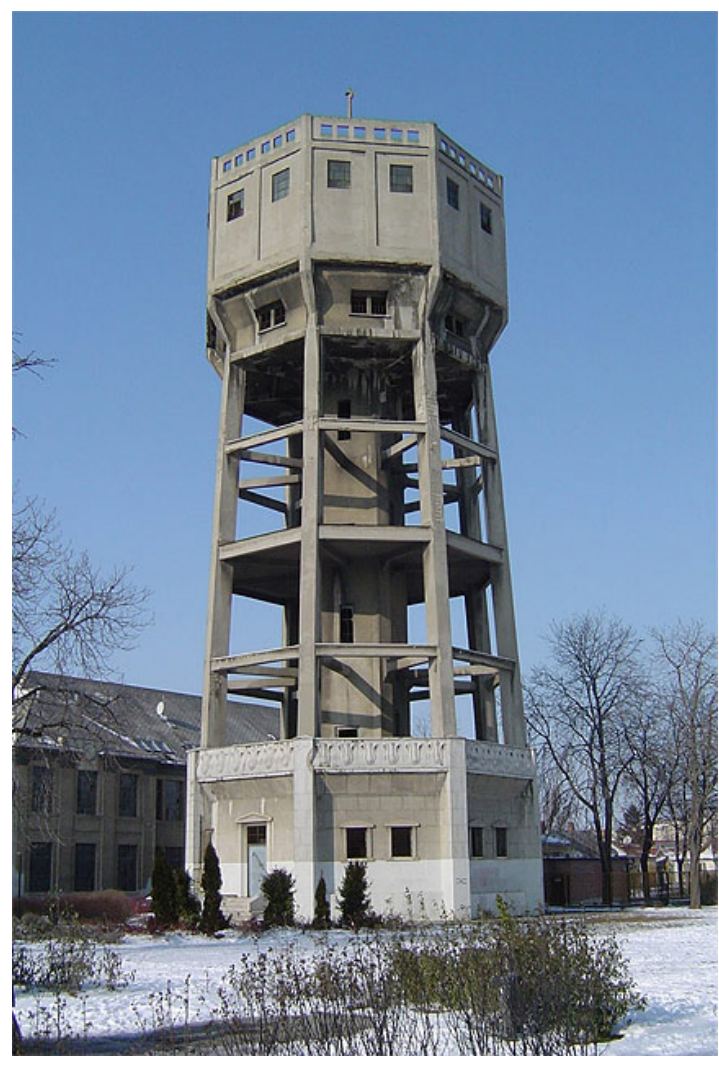

Fig. 15. The water tower on Eötvös tér in Szolnok was designed and constructed by Ede Ast \& Co. in 1910. Photo: András Lánczi

cessible for visitors. The dimensions and the arrangement of the staircase enable a comfortable vertical access leading towards the viewpoint on the roof-terrace of the tower. In addition the actual technology permits the presence of two permanent exhibitions in the tower for the delight of the visitors. This complexity of the actual forms of use is in great part due to Zielinski's genius and foresight. He knew that a new technology can only become popular and respected by the public if it has something to offer to its environment besides the fulfillment of the function that it was destined to. With the help of his architect collaborators he found the aesthetical way of expression of urban $\mathrm{RC}$ structures, that the citizens can consider as their own heritage. Hence the popularity of the tower on Margaret Island, too. It has became a listed industrial monument in 1977 after nearly twenty years of disuse. The walls of its tank has already been removed and except for this ruinous upper part closed for the public, the whole of its shaft is used for exhibitions. The open-air theatre which attracts many people during the summer season is at the foot of the tower. Visitors can have a full scale view over the Island and Budapest from the $33 \mathrm{~m}$ high loggias.

About the use or reuse of the towers in Belcsény and Temesvár no exact information has been found. The details of their history and their present-day state will be discussed in a forthcoming study. Studies emphasizing their architectural values may significantly contribute to their protection. Since they belong to the Hungarian industrial heritage, Hungarian specialists should pay adequate attention to them as well.

The latest water tower of Zielinski is on Eötvös út. It is a 


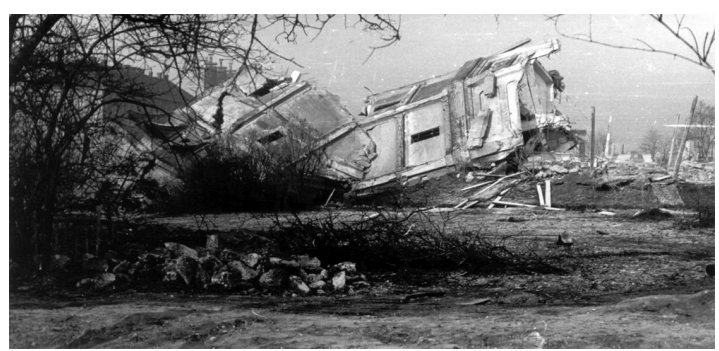

Fig. 16. The ruins of the water tower of Kóbánya at the end of 1968. Source: private postcard collection of Tibor Sebők

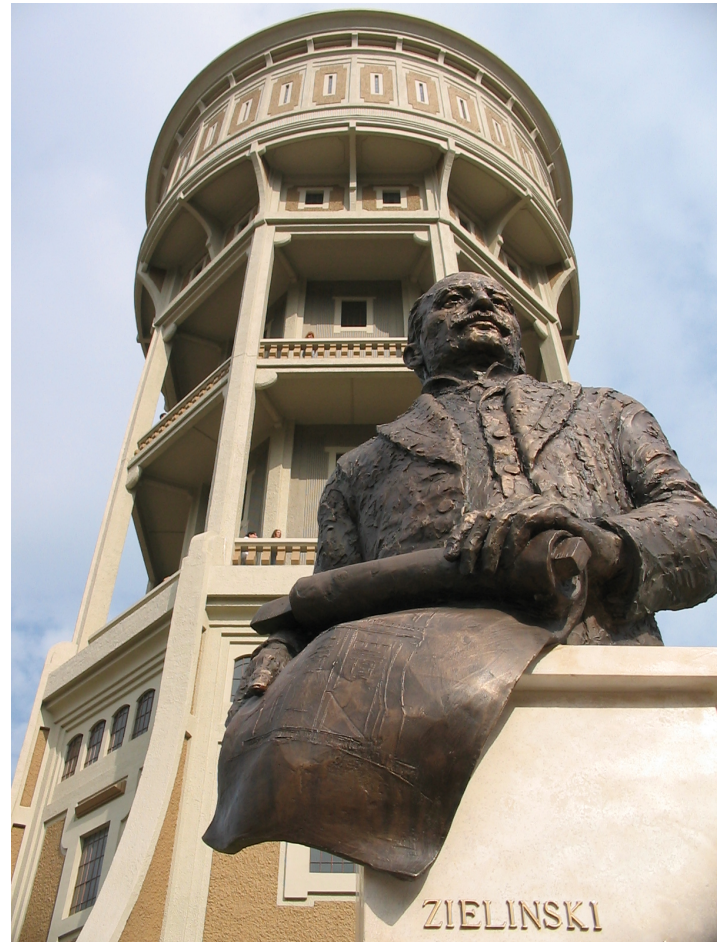

Fig. 17. The statue of Zielinski in the park on Szent István tér surrounding the water tower of Szeged. Photo: author

listed industrial monument, and it is still an important element of the water supply network in Buda. In a couple of years' time it is going to become a century old together with the tower of Margaret Island. These (and all the other) masterpieces of the Zielinski engineers' bureau would deserve appreciation in the new millennium.

\section{References}

1 Barton B, Water towers of Britain and their part in bringing water to the people, The Newcomen Society, London, 2003.

2 Gábor-Szabó Zs, Góztorony, Budapest University of Technology and Economics, Budapest, H, 2004. Master's thesis.

3 Gould M H, Cleland D J, Development of design form of reinforced concrete water towers, Proceedings of the Institution of Civil Engineers Structures \& Buildings 146 (2001), no. 1, 3-16, DOI 10.1680/stbu.146.1.3.40545.

4 Hajós Gy, Zielinski Szilárd, LOGOD Bt., Budapest, 2004.

5 Mihailich Gy, Haviár Gy, A vasbetonépités kezdete és elsô létesítményei Magyarországon, Akadémiai Kiadó, Budapest, 1966.

6 Révész A I, Vargha V (eds.), Magyar múszaki alkotók, Múszaki Kiadó, Budapest, 1964. 